\title{
THE PERFORMANCE CONTEXTS OF TROCHAIC TETRAMETERS CATALECTIC
}

\author{
Ewen Bowie* \\ Recebido em: 17/11/2018 \\ Aprovado em: 14/12/2018
}

$*$ Corpus Christi
College, Oxford.

ewen.bowie@ccc.ox.ac.uk

\begin{abstract}
The paper explores the evidence for the archaic performance context or contexts of Archilochus' and Solon's trochaic tetrameter catalectic poems, noting that they were chanted rather than sung or spoken and thus different from both elegy and iambic trimeters. It argues that in Archilochus' fragments apparently lengthy battle-narratives, concern with the polis as a whole, and addresses to elite individuals point to their first audience being a formal gathering of warrior-citizens, perhaps before a battle, or perhaps at a mass cremation following a battle such as that attested by the late-eighth-century polyandrion in Paroikia. It is suggested that Solon's very political tetrameters may also have been addressed to a formal citizen assembly, with possible reperformance at the Apatouria.
\end{abstract}

KEYWORDS: Archilochus; aulos; cremation; elegy; epitaphios; inscription; military; Paros; rhapsodia; Solon; tetrameter; Thasos; trochaic.

\section{OS CONTEXTOS DE PERFORMANCE DOS TETRAMMETROS TROCAICOS CATALÉTICOS}

RESUMO: O artigo explora a evidência do contexto ou dos contextos da performance arcaica dos poemas em tetrâmetro trocaico catalético de Arquíloco e Sólon, observando que eram entoados mais do que cantados ou falados e, portanto, diferentes tanto da elegia quanto dos trímetros iâmbicos. Argumenta-se que, nos fragmentos de Arquíloco, narrativas de batalhas aparentemente longas, preocupação com a polis como um todo e falas dirigidas a indivíduos da elite apontam para a hipótese de que a sua primeira audiência era um encontro formal de cidadãos-guerreiros, talvez antes de uma batalha, ou talvez em uma cerimônia de cremação em massa que se seguia a uma batalha, tal como a atestada pelo polyandrion do final do século oito em Paroikia. É sugerido que os próprios tetrâmetros políticos de Sólon também podem ter sido dirigidos a uma assembleia formal de cidadãos, com possível repetição de performance na Apatouria.

PALAVRAS-CHAVE: Arquíloco; aulos; cremação; elegia; epitaphios; inscrição; militar; Paros; rhapsodia; Sólon; tetrâmetro; Thasos; trocaico. 


\section{INTRODUCTION}

In this paper I explore the meagre evidence for the archaic performance context or contexts of poems in the metre that modern scholars (following metricians of the Hellenistic and Roman periods) call the trochaic tetrameter catalectic. ${ }^{1}$ Some features of these trochaic tetrameters might support the view that their performance contexts were different from those of other early verse forms - from those of melic poetry (always sung), of elegiac poetry (either sung or perhaps chanted), ${ }^{2}$ and of iambic trimeters (usually spoken, not sung) to which they are metrically close. ${ }^{3}$

I begin with a brief discussion of this last feature, the place on the spectrum between spoken and sung performance occupied by tetrameters. It seems that when trochaic

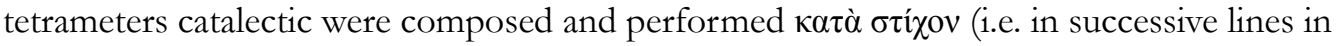
the same metre $)^{4}$ they were chanted, rather than sung or simply spoken: the ancient term is $\pi \alpha \rho \alpha \kappa \alpha \tau \alpha \lambda$ orn. ${ }^{5}$ It may be a consequence of the fact that they are 'chanted', rather than spoken, that they later have a strong presence in fifth-century Attic tragedy for stately speeches by serious characters, and in fifth-century Attic comedy for the sections of the parabasis that were not sung. These presences in turn might deserve to be taken into account in assessing archaic performance context.

Two other features that may be fruitful for determining performance context are (a) that some poems in this metre were addressed to elite citizens (though of course that was also the case for much elegiac and iambic poetry apparently performed in the symposium); and (b) that some both have a content that concerns the whole polis and a perspective that identifies itself with that of the polis as a whole, and not just (like much elegiac and iambic trimeter poetry) the perspective of a sympotic group. Of course some elegiac and iambic poetry does indeed address the good of the polis, and sometimes the perspective of the performer is aligned with that of the polis. ${ }^{6}$ But often both singer and immediate audience seem to stand outside the polis rather than being presented as an integral part of it. ${ }^{7}$

\footnotetext{
${ }^{1}$ I am very grateful to Elizabeth Irwin for helpful criticism of an earlier draft of this paper.

${ }^{2}$ For arguments in favour of the view that elegiac poetry was not sung but delivered in some mode intermediate between speech and song see Budelmann and Power (2013).

${ }^{3}$ But not as close a suggested by West (1980, p. 40), as has been pointed out e.g. by Sicking (1981, p. 427).

${ }^{4}$ The metre can also be found in melic metrical systems, e.g. in Alcman's first Partheneion, and in these the lines in this metre will have been sung just like adjacent lines in different metres.

${ }^{5}$ [Plut.] De Musica $28=$ Mor. 1141a. Note the self-referential ö $\varepsilon \delta \varepsilon$ in the tetrameter fr. 117 of Archilochus (discussed below), and the ö $\varepsilon 1 \delta \varepsilon$ of the tetrameter of Simonides fr. 92.2 (in West, 1992

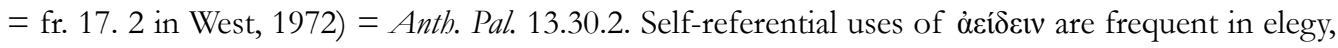
often with the phrase $\dot{v} \pi$ ' $\alpha \dot{\lambda} \lambda \eta \tau \tilde{\eta} \rho \varsigma$ (e.g. Theognidea 533), but the only appearance of $\dot{\alpha} \varepsilon i \delta \varepsilon \varepsilon v$ in trimeter fragments (Archilochus fr.58.12 öı $\delta \omega v$ vं $\pi^{\prime} \alpha \hat{\jmath} \lambda \eta \tau \tilde{\eta} \rho \varsigma_{)}$) has little claim to being self-referential.

${ }^{6}$ This is especially true of Solon (Irwin, 2005); but see also, e.g., Theognidea 757-64, 773-88, perhaps 453-56.

${ }^{7}$ E.g. Archilochus 13, Mimnermus fr. 7 (= Theognidea 795-6), Theognis 39-52, 53-68, 219-20, 541-542, Theognidea 287-92, 603-4. All fragment numbers of Archilochus, Hipponax, Mimnermus and Solon
} 


\section{ArChilochus}

By far our largest surviving body of trochaic tetrameters is attributed to Archilochus, and it seems to me that the text of these tetrameters offers some clues.

On the one hand, some of Archilochus' trochaic tetrameters, like many of his iambic trimeters and some of his epodes, are sexual narratives which it is tempting to allocate to some sort of sympotic performance, like fr. 118 and fr. $119,{ }^{8}$ or they concern his quarrel with Lycambes, like fr. 122: ${ }^{9}$ i.e. they are very much focussed on his personal life, whether real or constructed.

But the combination of papyri and inscriptions, above all, the two magnificent inscriptions from Paros, ${ }^{10}$ have established that there were long poems narrating battles between Parians and other contenders for control of land in the peraea along the Thracian coast opposite their colony on Thasos - Thracians, Naxians and perhaps Lesbians. ${ }^{11}$ The fragments of these poems repeatedly use first person plural verbs to describe the actions of the Parian fighters, ${ }^{12}$ and seem very much to adopt a polis perspective. They memorialise the fighters' achievements in a way that makes this poetry as important a forerunner of historiography as early narrative elegy. ${ }^{13}$ Indeed they offered enough information for Archilochus' admirer Mnesiepes in the third century BC, ${ }^{14}$ and the local historian Demeas, as cited by Sosthenes in the first century BC, ${ }^{15}$ to attempt to construct a historical narrative - a narrative in which Demeas thought he could attach different events to different archons. ${ }^{16}$ This is something to which I return.

But the poems are not simply narrative. The mixture of narrative, reflection and exhortation is well brought out by the following lines (= fr. 89.1-18, 26-30) which I print together with the prose text of Mnesiepes which introduces them. ${ }^{17}$ The passage is chiefly

refer to the numeration of West (1971-1972). For arguments that Archilochus used his epodic poetry to attack political enemies see Bowie (2008).

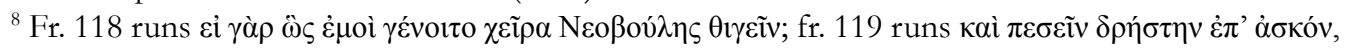

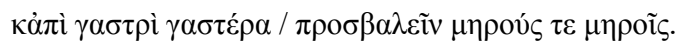

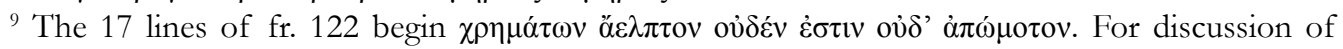
whether it is right to link this fragment with Archilochus' quarrel with Lycambes (as is usually done) see Bowie (2008).

${ }^{10}$ For these inscriptions and the light they cast on the cult of Archilochus at Paros see above all Clay (2004).

${ }^{11}$ Thracians, fr. 93a.6 ( = IG xii 5445 A I 49, cf. fr. 93b = Paus. 7.10.6); Naxians, fr. 89.6 (=SEG 15.517 B I 10), fr. 94 ( = IG xii 5445 A I 54); Lesbians fr. 98.11W (=IG xii 5445 A IV 12).

${ }^{12}$ Fr. 98.10 and 14, fr. 101.1 , fr. 106.2 and 4.

${ }^{13}$ For the importance of elegy as a predecessor of historiography see Bowie, 2001; Bowie, 2010; Bowie, 2018.

${ }^{14}$ SEG 15.517.

${ }^{15} I G$ xii $5.445=$ SEG 17.518.

${ }^{16}$ Fr. $192 \mathrm{~W}=I G$ xii 5.445.7-9.

${ }^{17}$ I.e. SEG 15.517 B I 4-47. 
narrative, but reflection is found at fr. 89.14-15, and the imperative $\gamma v \tilde{\omega} \theta \mathbf{u} v \tilde{v} v$ at fr. 89.17 supports Mnesiepes' reading of what he goes on to cite as exhortatory. ${ }^{18}$

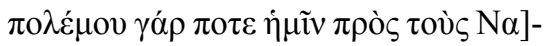

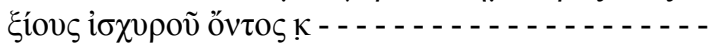

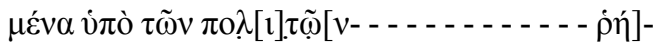

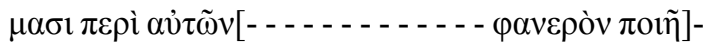

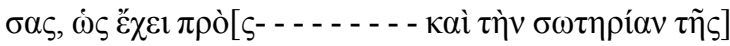

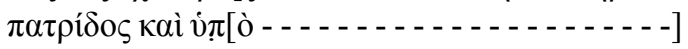

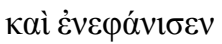

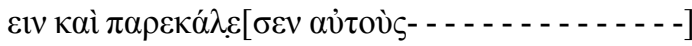

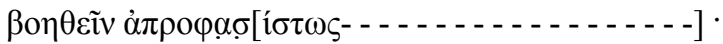

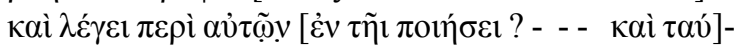

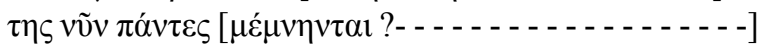

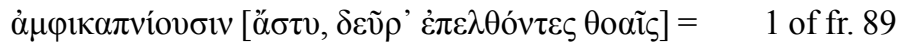

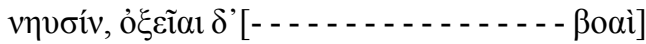

$\delta \eta \hat{i} \omega v, \alpha u ̉ \alpha i ́ v \varepsilon \tau[\alpha 1 \delta \grave{\varepsilon}-\ldots \ldots$

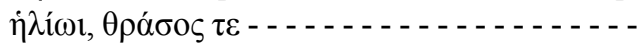

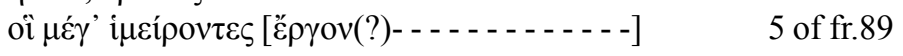

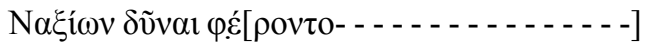

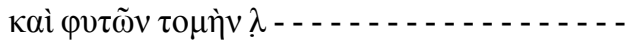

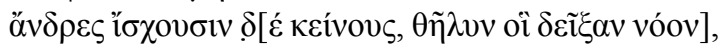

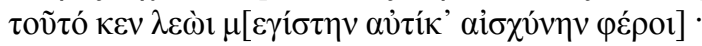

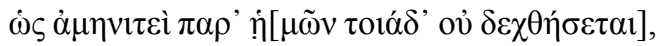

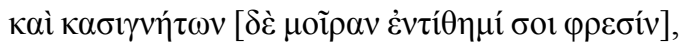

$\tau \varepsilon \dot{\varepsilon} \omega \nu \dot{\alpha} \pi \dot{\varepsilon} \theta \rho i \sigma \alpha \nu$

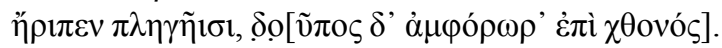

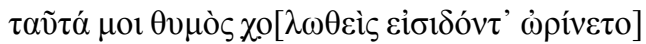

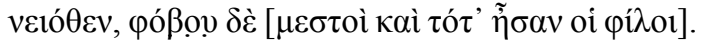

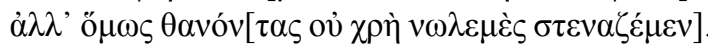

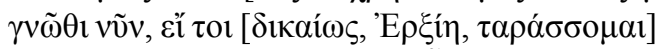

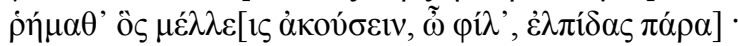

$\dot{\varepsilon} \mu \pi \rho \circ \alpha \sigma \tau i ́ \omega t \kappa \varepsilon[\chi \lambda \eta \delta$ ò $\varsigma$

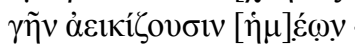

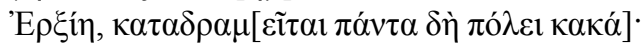

$\tau \tilde{\omega} ' \varsigma$ ódòv $\sigma \tau \varepsilon \lambda \lambda[$

$\mu \eta \delta \dot{\varepsilon} \delta \varepsilon \xi$ íovৎ $\varepsilon \pi[$

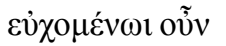

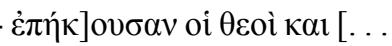

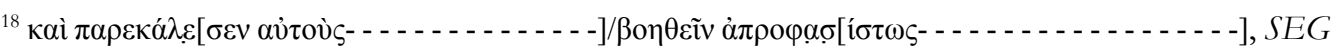
15.517 B I 11-12. I print the text with the supplements accepted by the editors of SEG 15, based on the editio princeps of Kondoleon (1952), the thorough discussion by Peek (1955) and the further suggestions of Peek (1956).
} 


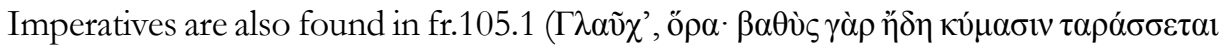

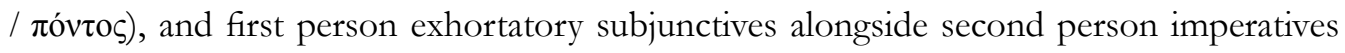
in fr. 106:

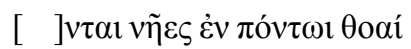

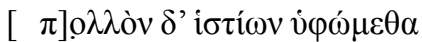

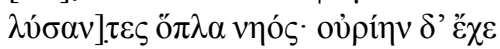

$$
\begin{aligned}
& \text { [ ] ] } \\
& \text { [ ] ] ] } \\
& \text { [ ] ] }
\end{aligned}
$$

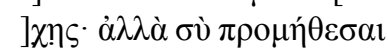

$$
\begin{aligned}
& \text { [ ] ] }
\end{aligned}
$$

An exhortation similar to the $\gamma v \tilde{\omega} \theta t v v v$ of fr. 89 is found in fr. 113.7-9: ${ }^{19}$

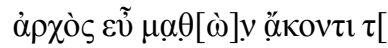

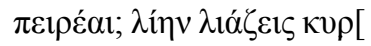

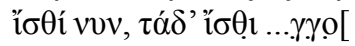

It may of course be questioned whether fr. 105 and the apparently related fr. 106 are from the same sort of battle-related poem: to me it seems likely that they are, but currently this cannot be demonstrated. At least the critical words addressed to Glaucus in

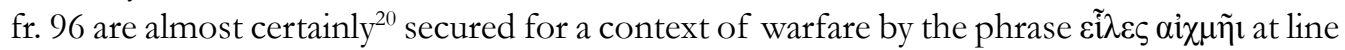
5 , supporting the contextualization of these lines after somebody's military victory ( $\mu \alpha \dot{\alpha} \chi \eta$ $\kappa \rho \alpha \tau \eta \sigma[\ldots])$ in Sosthenes' prose narrative:

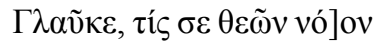

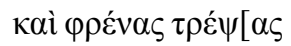

$\gamma \tilde{\eta} \varsigma \dot{\varepsilon} \pi \mu v \eta \dot{\sigma} \sigma \alpha 10 \tau[\tilde{\eta} \sigma \delta \varepsilon$

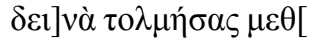

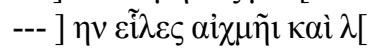

In fr. 89, finally, there was apparently, though not obvious in our surviving text, a prayer, whether by the poet or by one of his actors (and if one of these, probably Erxies);

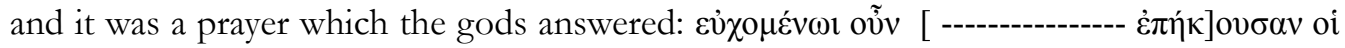
$\theta \varepsilon o i ̀$ (the line of prose following the quotation of fr. 89 printed above).

Archilochus' recurrent focus on the polis and the probable length of these poems - fr. 91 , incomplete at its beginning and end, runs to 46 lines, and must have been substantially longer when complete - both seem to me to count against primary performance of complete

\footnotetext{
${ }^{19}$ Not from the Parian inscriptions but from P.Oxy. 2314 col. i. West plausibly marks the words $\dot{\alpha} \rho \chi \grave{\varsigma} \varsigma$

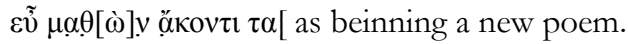

${ }^{20}$ I say 'almost certainly' because Archilochus uses the same phrase at fr. 23.19 in what appears to be a sexual context (Bowie, 2008, p. 139, with references to earlier discussions at n.15).
} 
poems in the symposium, but it would be unwise to exclude the possibility entirely. ${ }^{21}$ And as far as re-performance goes, I could readily imagine striking sections of such a trochaic poem being delivered to a sympotic audience.

One factor that may have tempted some (including me) to propose sympotic performance is that at least some such tetrameter poems of Archilochus seem to have been addressed to individuals. Thus fr. 88 is almost certainly the opening line of a poem addressed to Erxies, since it is quoted as an example of the metre - and metricians characteristically

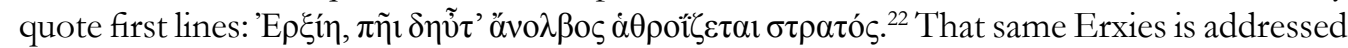
at fr. 89.28 , in the middle of a poem - quite probably the same poem as was opened by fr. 88 , and certainly, as we have seen, a poem set in the context of a war against Naxians, and in the view of Mnesiepes involving encouragement by Archilochus to his fellow-fighters.

Fr. 105 quoted above is also probably a first line, but less certainly so than fr. 88, addressed to Glaucus, the same Glaucus to whom Archilochus addressed, presumably in a symposium, the iambic trimeter erotic narrative of fr. 48; perhaps the hexameter fr. 15; whom he perbaps apostrophised in mid-narrative in the tetrameters of fr. 96.1 (quoted above); and to whom he certainly addressed the gnome of fr. $131 .^{23}$

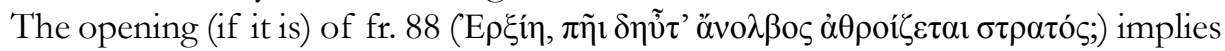

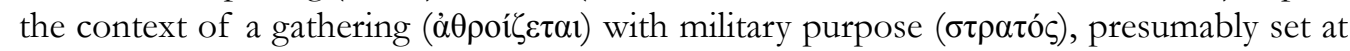
a critical time when war was yet again ( $\left.\delta \eta \tilde{v} \tau^{\prime}\right)$ imminent. The adjective indicates that the $\sigma \tau \rho \alpha$ ó $\zeta$ has relatively recently suffered a serious reverse.

Why are Erxies and Glaucus addressed? We might guess that Erxies and Glaucus are $\sigma \tau \rho \alpha \tau \eta \gamma o$ or or the like. We do not know if there was a difference between a $\sigma \tau \rho \alpha \tau \eta \gamma \delta \varsigma$ and an äp $\chi \omega v$ in the seventh century Parian settlement on Thasos: so when in fr. 113.7-9 the poet

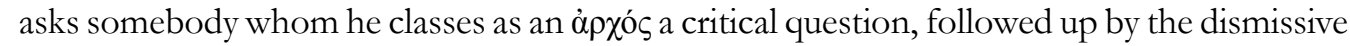
$\lambda i \alpha v \lambda i a ́ \zeta \varepsilon 1 \zeta$, 'you shrink back too readily', the context might again be military rather than political. ${ }^{24}$ In one of his criticism of leading figures he uses the term $\sigma \tau \rho \alpha \tau \eta \gamma o ́ \varsigma-$ the four tetrameters much quoted in the second century $\mathrm{AD}$, fr. 114, on the superiority of a short but

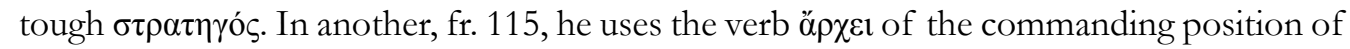
one Leophilus, a position which he seems to find oppressive. Such critical remarks could well

${ }^{21}$ On the length of sympotic performances see Bowie (2016), concluding that despite their length Solon fr. 13 (76 lines) and perhaps even his Salamis (100 lines, according to Plutarch) were probably first performed in a sympotic context.

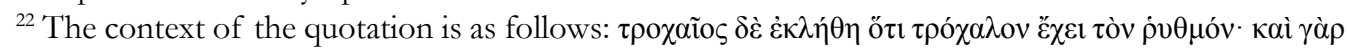

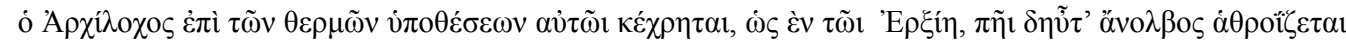

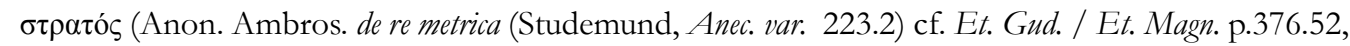
Hephaest. Ench. $6.2+$ schol. p. 271.6 \& 21 Consbruch).

${ }^{23}$ This Glaucus son of Leptines (fr. 131.1) is surely the same as the man of that name and patronymic commemorated in the agora of archaic Thasos (Grandjean, Salviat and Blondé, 2000, p. 69, with plate $29)$, i.e. an historical individual.

${ }^{24}$ Fr. 114 famously criticizes a tall and elegantly turned out $\sigma \tau \rho \alpha \tau \eta \gamma$ ś fr. 115 uses the verb ä $\rho \chi \varepsilon ı$ of the commanding position of one Leophilus which the poet seems to find oppressive. 
be accommodated in an address to a $\sigma \tau \rho \alpha \tau$ ó, but it must be admittedly that they could equally belong to poems intended for performance in a sympotic context, as is usually thought. If some of the addressees of the Archilochean battle narratives were both identified there as archons and/or were known to the later historian Demeas as having held the archonship, it becomes much easier to understand why he believed that he could offer a chronological frame for his account of the activity of Archilochus on seventh-century Paros and Thasos, as he claimed according to SEG 15.518 column I 1-9:

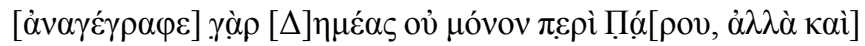

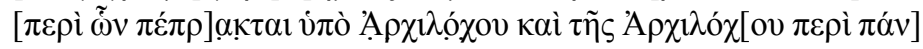

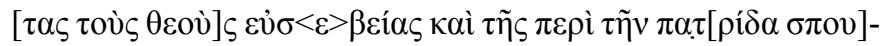

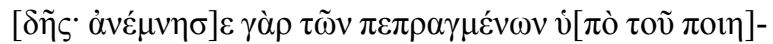

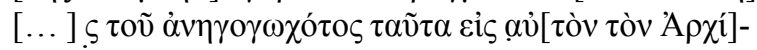

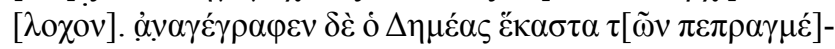

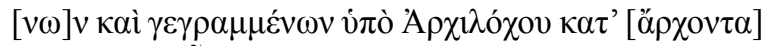

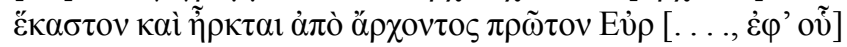

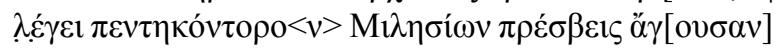

It seems, however, that in one tetrameter poem presumably focused on polis-issues (fr. 109.1-2) the addressee was not an elite individual but the citizenry at large. ${ }^{25}$ It is the only address to $\pi \mathrm{o} \lambda \tau \tau \alpha \mathrm{l}$ in the surviving corpus of elegiac and iambic poetry, and one of only four uses of the term $\pi$ o $\lambda$ ín $\varsigma$ in that corpus. ${ }^{26}$ The only place where such an address to citizens or groups of citizens is audible in elegiac poetry is in Solon fr. 4; and there, as

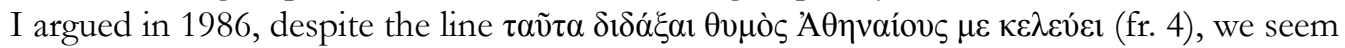
rather to have 'an elegy in which, probably within an expository framework where Solon did speak in his own person, one set of sentiments was encapsulated as the views of the rich addressed to the $\mu \varepsilon \dot{\sigma} \sigma 0 t$ and another as the views of the $\mu \varepsilon \dot{\sigma o l}$ addressed to the rich. It will have been this framework (presumably of the form "the rich could well say to the $\mu \dot{\varepsilon} \sigma o \imath$ " and "the $\mu \varepsilon \varepsilon \sigma o r$ could well say to the rich") that made it clear to the author of the Athenaion Politeia what was happening. The poem as a whole from which our fragments come need have been addressed neither to the rich nor to the $\mu \dot{\varepsilon} \sigma 01$, nor somehow to both groups. ${ }^{27}$ By contrast, in Archilochus fr. 109 we have direct address to $\pi \mathrm{o} \lambda \tilde{\tau} \tau \alpha$ :

$<\tilde{\omega}>\lambda ı \pi \varepsilon \rho v \tilde{\eta} \tau \varepsilon \varsigma \pi \mathrm{o} \lambda \tilde{\tau} \alpha \alpha, \tau \dot{\alpha} \mu \alpha \grave{\alpha} \delta \grave{\eta} \sigma v v i \varepsilon \tau \varepsilon$

$\dot{\rho} \eta \mu \alpha \tau \alpha \ldots$

\footnotetext{
${ }^{25}$ Quoted by the scholia on Aristophanes, Peace 603. It is worth asking whether Aristophanes, in reworking this tetrameter in Peace (as it is also said by the scholiast that Cratinus did in his Pytine) knew it from a sequence whose other lines indicated that, like Hermes in Peace, Archilochus was explaining or commenting on the origins of a conflict of the Parians on Thasos with either Naxians or Thracians. ${ }^{26}$ The other three are Mimnermus fr. 7 (= Theognidea 795-6), Theognis 219-20 and Theognidea 455. There are many more uses of the term $\dot{\alpha} \sigma \tau$ ó $\zeta$, but none is in the vocative.

${ }^{27}$ Bowie, 1986, p. 20.
} 
We cannot be so sure that this is the opening line of a poem as we can in the case of fr. 88. It may be have been a rhetorical reinforcement of some advice in which it was

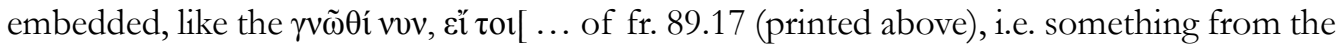
middle of a poem. But wherever it stood, it suggests that the sequence of which it was a part was directed to a plurality of $\pi$ o $\lambda \tilde{\tau} \tau \alpha$. It may be worth recalling that Hipponax's choliambic

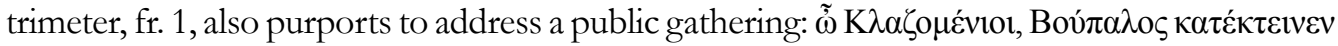
.... Hipponax may be posturing in a poetic mode he knows from Archilochus.

One very probable context for first performance of these long tetrameter poems, then, seems to me to be a gathering of the Parian $\sigma \tau \rho \alpha \tau$ ó on Thasos, called by a strategos or archon who will lead this $\sigma \tau \rho \alpha \tau$ ó (yet again, $\delta \eta \tilde{v} \tau \varepsilon$ ) into battle. The context is thus not dissimilar to that for the singing of Tyrtaeus' elegiac martial exhortatory songs in the Spartan royal skene which I tried to reconstruct in 1990, working from Philochorus FGrH 328 F216 and Lycurgus, in Leocratem 107. ${ }^{28}$ That around 650 BC Archilochus might do with trochaic tetrameters on Thasos what Tyrtaeus at about the same time, followed by later generations of Spartans, chose to do with elegy should be interesting but not surprising. And it may be a corollary of the fact that, despite Peek's precarious attempt to create four lines of martial exhortatory elegy from the Sosthenes monument, ${ }^{29}$ and despite many papyri and quotations, we have no certain martial exhortatory elegy for Archilochus. ${ }^{30} \mathrm{~A}$ fragment of elegiac poetry almost certainly by Archilochus, Adespota elegiaca $61 \mathrm{~W}$ (P.Oxy. 2507), offers a narrative not dissimilar to those in the tetrameter fragments, but no demonstrable reflection or exhortation. ${ }^{31}$

There is also, however, another way of interpreting our very scanty evidence. On

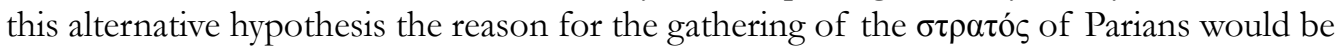
the formal burial of the dead after a battle or battles. The Archilochean poems would then become some sort of ancestors of the fifth-century Attic logos epitaphios. The prime focus of such an address will predictably be on the achievements of the fallen warriors, but there is room in the rhetoric for encouragement to the survivors to fight even more fiercely, albeit more prudently.

In favour of this hypothesis might be seen the occasional zooming-in on the death of a warrior, e.g. fr. 89.13: ท̆ lines see the fuller quotation above). Moreover a palmary context might thus be offered for fr. 108W:

\footnotetext{
${ }^{28}$ Bowie, 1990.

${ }^{29}$ Fr. 7: Peek, 1985, p. 14.

${ }^{30}$ Some scholars have interpreted the narrative of Telephus' defence of Mysia in the new elegiac fragment of Archilochus, P.Oxy. 4708, as an exemplum relating to a contemporary war situation; but although it begins with a gnome there is no exhortation in the surviving lines, and for the view that the poem was rather a mythological narrative see Bowie (2010).

${ }^{31}$ P. Oxy. 2507 was tentatively ascribed to Archilochus by its editor Lobel in 1964. That ascription was shown to be correct by Henry (1998).
} 


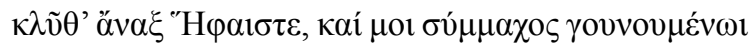

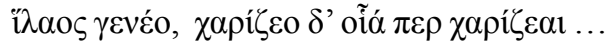

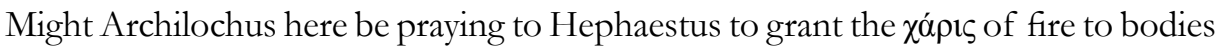
which were about to be cremated? Admittedly Plutarch, who quotes these two lines, took the view that in these lines Archilochus was praying (घủó $\mu \varepsilon v o s)$ to the god himself and was

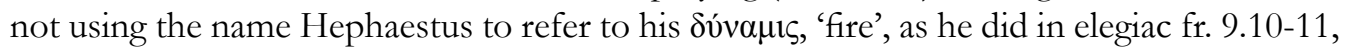
which Plutarch also quotes. ${ }^{32}$ Perhaps Plutarch knew enough of the poem on either side of these lines to establish the distinction he wants, but it should be worrying that he is clearly looking around for passages which do establish that distinction. That fr. 108 is a prayer in the context of a cremation ceremony seems to me to remain a possibility: the $\chi \alpha$ ás that Hephaestus characteristically gives is fire, but it is a prayer to him as a deity that will ensure that a funeral pyre burns effectively.

It might be objected that on both Paros and Thasos in the archaic period the predominant form of burial was inhumation. ${ }^{33}$ Until some 30 years ago that would have been a serious objection. But in the late 1980s two large collective cist-graves were discovered near the harbour of the city of Paros (Paroikia, the island's chora), dated to the late eighth century BC, which contained amphoras in which were found the bones of some 120 men between the ages of 18 and 45 - in one case a spear-head was embedded in a bone: these men had been cremated and their bones had been cleaned before they were deposited in the amphoras. ${ }^{34}$ On current (probable reliable) chronologies this polyandrion is some two generations before Archilochus. But it shows that, after a battle in which there were substantial losses, the Parians of the archaic period might resort to mass cremation and burial of their war dead.

\section{SOLON: FIRST PERFORMANCE OF SOLON'S TETRAMETERS}

If what I have suggested for Thasos in the middle of the seventh century is correct then Solon's political tetrameters too may have had some similar sort of context of performance, rather than the symposium, and they might bring with them Solon's very similarly textured iambic trimeters. ${ }^{35}$ It might be suggested that the story of Solon performing his elegiac, 100-line poem Salamis in the agora was a confused memory of such performances. That elegies were characteristically sung or chanted to the accompaniment of an aulos still seems to me now, as it did in 1986, one of several reasons to reject this tradition about the performance of the Salamis, ${ }^{36}$ for although there were locations outside the symposium

\footnotetext{
${ }^{32}$ Plutarch quotes fr. $108 \mathrm{~W}$ and fr. $9.10-11 \mathrm{~W}$ at de poetis audiendis $6=$ moralia $23 \mathrm{a}-\mathrm{b}$.

${ }^{33}$ For Thasos cf. the graves that yielded the jewellery discussed by Sgourou and Agelarakis (2001).

${ }^{34}$ See Blackman (1996/1997), Zaphiropoulou and Agelarakis (2001), Lloyd (2018), Agelarakis (2018).

${ }^{35}$ For a wide-ranging examination of Solon's political poetry, emphasizing the importance, above all for his elegies, of sympotic performance contexts, see Irwin (2005).

${ }^{36}$ Bowie, 1986, p. 18-21.
} 
where an aulos could be played - such as when an army was marching into battle, or in performances in a theatre - a public meeting called to debate policy was not one of these locations. But the absence of an aulos would not be a reason for denying that tetrameters might be performed at some sort of public meeting.

\section{RE-PERFORMANCE OF SOLON AT THE APATOURIA?}

One other context in which Plato in the Timaeus presents Solonian poetry as being re-performed is in competitions at the Apatouria:

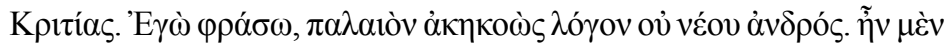

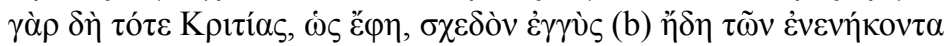

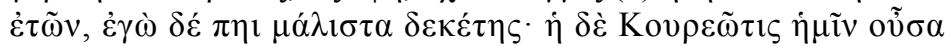

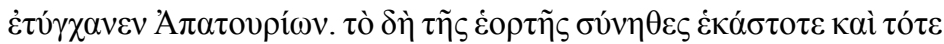

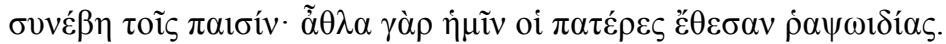

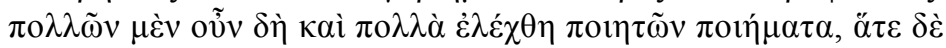

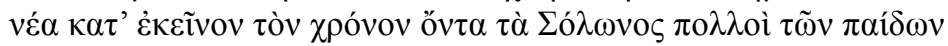

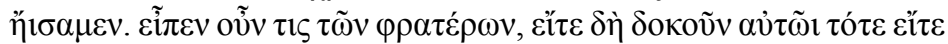

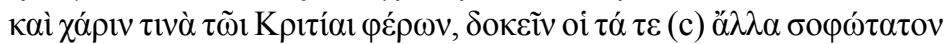

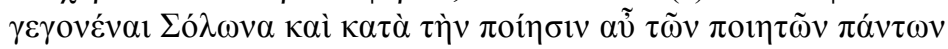
$\dot{\varepsilon} \lambda \varepsilon v \theta \varepsilon \rho \iota \omega ́ \tau \alpha \tau o v$. (Plato, Timaeus 21a-c)

This statement (if reliable) locates musical competitions ( $\tilde{\alpha} \theta \lambda \alpha$ ) between $\pi \alpha \tilde{i} \delta \varepsilon \varsigma$ on the Koureotis - the third day of the Apatouria - so called because on that 'cutting day' a lock or locks of ephebes' hair was cut and ritually offered before the animal sacrifice. This ceremony marked their becoming adult members of the phratry. ${ }^{37}$ If this happened at a ceremony conducted by a phratry then the numbers may have been relatively small, and in that respect the occasion was not dissimilar to a symposium; but Plato has Critias call it a $\dot{\varepsilon} 0 \rho \tau \eta \dot{n}$, and the competitions $(\tilde{\alpha} \theta \lambda \alpha)$ seem to be more formally structured than in the symposium, admittedly always inherently agonistic. There is no indication that wine is central to the rituals, or that any of the older men present gave musical performances. What the boys performed is of great interest: Plato has Critias claim that many of the boys sang poems of Solon because at that time they were 'new' ( $\left.v \varepsilon^{\prime} \alpha\right)$. One striking feature of Plato's language here is that he describes the $\pi \alpha \tilde{i} \delta \varepsilon \zeta$ as singing, and their performance as $\dot{\rho} \alpha \psi \omega i \delta i \alpha$. He does not, then, imagine competitions in playing the aulos, far less singing while accompanied by the aulos (principally, that is, the singing of elegy), but a performance involving young singers playing a stringed instrument as an accompaniment to singing, more probably a lyre (suitable for symposia) than a larger and more challenging cithara (appropriate for professional public performances). ${ }^{38}$

\footnotetext{
${ }^{37}$ The MSS of Plato Timaeus make the speaker Critias only ten at the imagined time, which is inconsistent with the other evidence linking the Koureotis with ephebic age, and I suspect Plato's text had a number in the mid-teens.

${ }^{38}$ For the difference between smaller lyra and the cithara see Power (2010).
} 
If there is any substance at all in Plato's idea that the $\pi \alpha \tilde{i} \delta \varepsilon \varsigma$ in the sixth century sang the recently composed poems of Solon, which of the genres across which that poetry was spread is most likely to have been sung? So far as we know Solon was never credited with hexameters, so the $\pi \alpha \tilde{i} \delta \varepsilon \varsigma$ did not sing hexameters in the way rhapsodes did in competition at the Panathenaea once that festival had been established. That they performed elegy is possible: even though the instrument with which the performance of elegy is predominantly associated is the aulos, I accept that mentions of the $\lambda$ óp $\eta$ accompanying singing at Theognidea 534 and 975 may be self-referential, and so may indicate that the lyra, always present in a symposium anyway, might be used to accompany elegy in the way that more often it was accompanied by an aulos. There remain iambic trimeters, which Aristotle famously regarded as nearest to ordinary speech, and trochaic tetrameters. Might the trochaic tetrameters of Solon, focussed on the problems of the polis, have been sung by $\pi \alpha \tilde{i} \delta \varepsilon \zeta$ on the verge of becoming adult $\pi \mathrm{o} \lambda \tilde{i} \tau \alpha \mathrm{l}$ at the Ionian Apatouria in Athens, and might other poets' tetrameters have been sung at Apatouria in other parts of the Ionian world?

\section{Archilochus ReVisited}

That the Apatouria might have been a possible context for the performance of tetrameters takes me back very briefly to Archilochus. If tetrameters were sung at the Parian or Thasian Apatouria, might the precocious $\pi \alpha \tilde{\imath} \varsigma$ Archilochus have sung not the songs of other

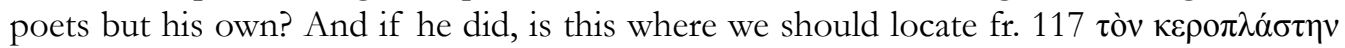
$\not \varkappa \varepsilon 1 \delta \varepsilon \Gamma \lambda \alpha \tilde{\kappa} \kappa o v$, 'sing of Glaucus with the horn-fashioned lock', picking out the distinctive hair-style of his friend Glaucus son of Leptines, who on this hypothesis would already be a friend from their childhood, as well as giving us a precious indication of sung performance if the word $\alpha \varepsilon 1 \delta \varepsilon$ is self-referential?

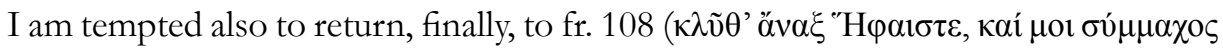

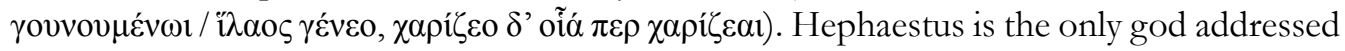
in Archilochus' tetrameters (though many others are referred to), and we know from the Hellenistic scholar Ister (FGrH 334 F2) that Hephaestus was especially associated with the Apatouria at Athens:

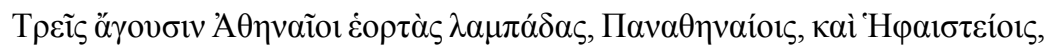

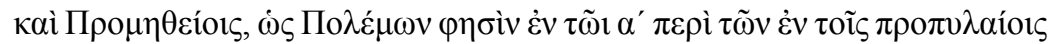

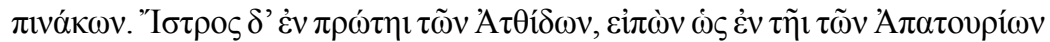

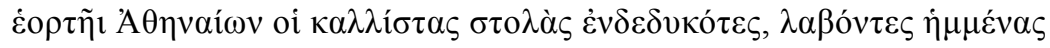

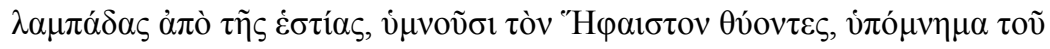

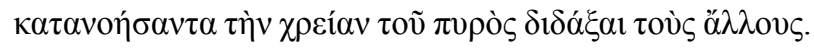

Harpocration s.v. $\lambda \alpha \mu \pi \alpha ́ \varsigma$ (= Istros, FGrH 334 F2)

Of course fr. 108 cannot belong both in a poem presented at the Apatouria by the young Archilochus and in a poem delivered at the burial of warriors by the mature soldierpoet Archilochus. But our ignorance of how tetrameters were performed in archaic Greek 
poleis is such that each possibility for which there is any evidence at all should be considered until it has been eliminated. The above discussion has attempted to exploit as many clues as can be detected to the performance contexts of poem in this metre: even if all these clues are found to be susceptible of different interpretations from mine, it will be a gain if scholars working in this field decide to think again about questions of tetrameter performance.

\section{REFERENCES}

AGELARAKIS, Anagnostis P. Parian Polyandreia: The Late Geometric Funerary Legacy of Cremated Soldiers' Bones on Socio-Political Affairs and Military Organizational Preparedness in Ancient Greece. Oxford: Archaeopress Publishing, 2018.

BLACKMAN, David. Archaeology in Greece. Archaeological Reports, v. 43, p. 1-125, 1996/1997. BOWIE, Ewen. Early Greek elegy, symposium and public festival. Journal of Hellenic Studies, v. 106, p. 1-35, 1986.

BOWIE, Ewen. Miles ludens. The problem of martial exhortation in early Greek elegy. In: MURRAY, Oswyn (Ed.). Sympotica. A symposium on the symposium. Oxford: Oxford University Press, 1990. p. 221-9.

BOWIE, Ewen. Ancestors of Herodotus in Early Greek Elegiac and Iambic Poetry. In: LURAGHI, Nino (Ed.). The Historian's Craft in the Age of Herodotus. Oxford: Oxford University Press, 2001. p. 45-66.

BOWIE, Ewen. Sex and politics in Archilochos' poetry. In: KATSONOPOULOU, Dora; PETROPOULOS, Ioannes; KATSAROU, Stella (Ed.). Archilochos and his age. Proceedings of the second International Conference on the Archaeology of Paros and the Cyclades, Paroikia, Paros, 7-9 October, 2005. Athens: Ekdoseis Diktynna, 2008. p. 133-41.

BOWIE, Ewen. Historical narrative in archaic and early classical Greek elegy. In: KONSTAN, David; RAAFLAUB, Kurt A. (Ed.). Epic and history. Malden MA and Oxford: Wiley-Blackwell, 2010. p. 145-66.

BOWIE, Ewen. Quo usque tandem? How long were sympotic songs? In: CAZZATO, Vanessa; OBBINK, Dirk; PRODI, Enrico E. (Ed.). The Cup of Song: Studies on Poetry and the Symposium. Oxford: Oxford University Press, 2016. p. 28-41.

BOWIE, Ewen. The Lesson of Book 2. In: IRWIN, Elizabeth K.; HARRISON, Thomas (Ed.). Interpreting Herodotus. Oxford: Oxford University Press, 2018. p. 53-74.

BUDELMANN, Felix; POWER, Timothy. The inbetweenness of sympotic elegy. Journal of Hellenic Studies, v. 133, p. 1-19, 2013.

CLAY, Diskin. Archilochos heros: the cult of poets in the Greek polis. Washington, DC: Center for Hellenic Studies, 2004. 
GRANDJEAN, Yves; SALVIAT, François; BLONDÉ, Francine. Guide de Thasos. $2^{\text {nd }}$ ed. Athens; Paris: École Française d'Athènes, 2000.

HENRY, William Ben. An Archilochus papyrus? Zeitschrift für Papyrologie und Epigraphik, v. 121, p. 94, 1998.

IRWIN, Elizabeth K. Solon and early Greek poetry: the politics of exhortation. Cambridge: Cambridge University Press, 2005.

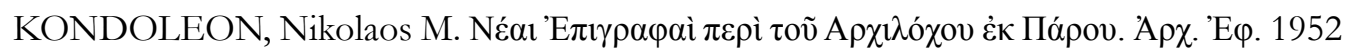
(1954) 32-95, with plates 3-4.

KONDOLEON, Nikolaos M. Zu den neuen Archilochosinschriften. Philologus, v. 100, p. 29-39, 1956.

LLOYD, Matthew. The dead are many. A polyandrion from Paros. 2018. Available from: <https://www.ancientworldmagazine.com/articles/dead-are-many-polyandrion-paros/>.

PEEK, Werner. Zu den neuen Archilochosinschriften. Philologus, v. 99, p. 4-50, 1955.

PEEK, Werner. Ein neues Bruchstück vom Archilochos-Monument des Sosthenes. Zeitschrift für Papyrologie und Epigraphik, v. 59, p. 13-22, 1985.

POWER, Timothy. The Culture of Kitharoidia. Washington, DC: The Center for Hellenic Studies, 2010.

SGOUROU, Marina; AGELARAKIS, Anagnostis P. Jewellery from Thasian graves. Annual of the British School at Athens, v. 96, p. 327-54, 2001.

SICKING, Christiaan M. J. Review of West (1982). Mnemosyne, v. 39, p. 423-32, 1986.

WEST, Martin L. Iambi et elegi graeci. Oxford: Oxford University Press, 1971-1972. [2 ${ }^{\text {nd }}$ edition 1989, 1992]. $2 \mathrm{v}$.

WEST, Martin L. Greek Metre. Oxford: Claredon Press, 1982.

ZAPHIROPOULOU, Photini N. Recent finds from Paros. In: STAMATOPOULOU, Maria; YEROULANOU, Marina (Ed.). Excavating Classical culture. Recent archaeological discoveries in Greece. Oxford: The Beazley Archive and Archaeopress, 2002. p. 281-4.

ZAPHIROPOULOU, Photini N.; AGELARAKIS, Anagnostis P. Warriors of Paros. Soldiers' burials offer clues to the rise of Classical Greek city-states. Archaeology, v. 58, p. 30-5, 2005. 
